University of Nebraska - Lincoln

DigitalCommons@University of Nebraska - Lincoln

Faculty Publications: Department of Entomology

October 1995

\title{
Environmental and Edaphic Effects on Western Corn Rootworm (Coleoptera: Chrysomelidae) Overwintering Egg Survival
}

\author{
L. D. Godfrey \\ University of Nebraska-Lincoln \\ Lance J. Meinke \\ University of Nebraska-Lincoln, Imeinke1@unl.edu \\ Robert J. Wright \\ University of Nebraska-Lincoln, rwright2@unl.edu \\ Gary L. Hein \\ University of Nebraska-Lincoln, ghein1@unl.edu
}

Follow this and additional works at: https://digitalcommons.unl.edu/entomologyfacpub

Part of the Entomology Commons

Godfrey, L. D.; Meinke, Lance J.; Wright, Robert J.; and Hein, Gary L., "Environmental and Edaphic Effects on Western Corn Rootworm (Coleoptera: Chrysomelidae) Overwintering Egg Survival" (1995). Faculty Publications: Department of Entomology. 98.

https://digitalcommons.unl.edu/entomologyfacpub/98

This Article is brought to you for free and open access by the Entomology, Department of at DigitalCommons@University of Nebraska - Lincoln. It has been accepted for inclusion in Faculty Publications: Department of Entomology by an authorized administrator of DigitalCommons@University of Nebraska - Lincoln. 


\title{
Environmental and Edaphic Effects on Western Corn Rootworm (Coleoptera: Chrysomelidae) Overwintering Egg Survival
}

\author{
L. D. GODFREY, ${ }^{1}$ L. J. MEINKE, R. J. WRIGHT, AND G. L. HEIN
}

Department of Entomology, University of Nebraska, Lincoln, NE 68583-0816

\begin{abstract}
J. Econ. Entomol. 88(5): 1445-1454 (1995)
ABSTRACT Western corn rootworm, Diabrotica virgifera virgifera LeConte, overwintering egg survival was studied at 3 soil depths $(7.5,15$, and $30 \mathrm{~cm}$ ), 3 soil textures (silty clay loam, loam, and sandy loam), and 2 surface residue treatments (with and without surface cover) at an eastern Nebraska site in 1989-1990 and 1990-1991. At a western Nebraska site, egg survival was evaluated at 3 soil depths $(7.5,15$, and $30 \mathrm{~cm}), 2$ surface residue regimes (with and without surface cover) within a fine sandy loam soil in 1989-1990. Overall, egg survival was low (30.0\%) and intermediate $(41.0 \%)$ at the eastern and western sites, respectively in 1989-1990 and high $(64.7 \%)$ at the eastern Nebraska site in 1990-1991. Egg survival was significantly influenced by surface residue and by depth in all soil textures at the eastern site during both seasons. Percentage survival of $D$. $v$. virgifera eggs was $<5$ and $\approx 15 \%$ in the bare surface treatment at the 7.5 and $15 \mathrm{~cm}$ depths, respectively in 1989-1990. In 1990-1991, the lowest survival occurred in the bare surface treatment at $7.5 \mathrm{~cm}$. Egg survival was not influenced by the surface cover or sample date at the western site. Simple regression equations showed significant relationships of percentage of egg survival with minimum soil temperature and with negative degree-days (1989-1990 only) at the eastern site. In 1990-1991, $\approx 80$ negative degreedays or a minimum temperature of $\approx-7^{\circ} \mathrm{C}$ was needed to significantly decrease $D$. $v$. virgifera egg survival. Multiple regression improved the prediction and showed the importance of snowfall and snow cover at the western Nebraska site and in 1990-1991 at the eastern site.
\end{abstract}

KEY WORDS Diabrotica virgifera virgifera, egg survival, overwintering, crop residue, soil

THE WESTERN CORN rootworm, Diabrotica virgifera virgifera LeConte, is the most important insect pest of field corn, Zea mays L., in the major production regions of the United States. Larvae of this insect are the primary damaging stage. Economic losses are a combination of corn physiological yield losses, harvest losses, reductions in corn nutrient quality, and costs associated with control actions. Currently, prophylactic applications of soil insecticides at planting are the primary means of corn rootworm larval control.

A method has been developed to monitor adult rootworm populations in cornfields in the summer as a means to predict fields unlikely to develop damaging larval populations the subsequent year. Research by Pruess et al. (1974) established this threshold at 1 beetle per corn plant. Godfrey and Turpin (1983) showed that the threshold in 1st-yr corn fields should be 0.75 beetles per plant. Several researchers have evaluated pilot programs of adult monitoring and found them to generally be accurate. Stamm et al. (1985) found this type of integrated pest management (IPM) program re-

\footnotetext{
${ }^{1}$ Current address: Department of Entomology, University of California,. Davis, CA 95616.
}

duced soil insecticide application by $80 \%$ in Lincoln County, Nebraska.

However, because of the long period between the occurrence of adults (July to September) and larval feeding the next year (June and July), there are inaccuracies in this method. Specifically, densities of rootworm adults above the threshold do not always result in economic damage the following year (Stamm et al. 1985, Foster et al. 1986). These inaccuracies, and the limitations to this type of IPM program, are likely caused by the range of environmental and edaphic conditions experienced by corn rootworms during the overwintering and larval establishment period.

Within Nebraska, western corn rootworms infest corn fields from the eastern part of the state, characterized by clay loam and silty clay loam soils, to the western and north central regions of the state, characterized by sandy texture soils (Elder 1969). These soil variations result in differences in soil moisture, soil temperature (frost line), and other environmental factors within the soil. The presence of crop residue on the soil surface may influence egg survival in several ways. Fall tillage, which disturbs the soil and destroys crop residue, may increase overwintering egg mortality by ex- 
posing the soil surface to winter cold temperatures (Rasmussen and Chiang 1967). Conversely, crop residue may favor egg survival by increasing soil moisture retention, including retaining snow cover during the winter. Calkins and Kirk (1969) found that when winter precipitation was plentiful, no differences occurred in rootworm larval populations between fall- and spring-plowed plots. During years with limited winter precipitation, populations were unexplainably higher in fall-plowed than spring-plowed plots. Lawson (1986) found that tillage treatments (altering crop residue and several soil characteristics) influenced western corn rootworm egg survival during 1 of 2 study years. Survival was higher (especially at 2.5 and $7.5 \mathrm{~cm}$ ) in the no-till situation than in 3 treatments with tillage operations.

The reliability of using summer adult density estimates to predict larval damage potential the following year depends on 3 facets of corn rootworm biology: (1) oviposition magnitude, (2) egg overwintering survival, and (3) larval survival and establishment. Gustin (1979) and Johnson and Turpin (1985) studied the influence of soil moisture and tillage system, respectively, on Diabrotica spp. oviposition. The objectives of our study were to examine western corn rootworm egg overwintering survival in 3 soil textures, 3 soil depths, and 2 crop residue treatments. Studies were conducted at 2 locations in Nebraska with varying environmental conditions.

\section{Materials and Methods}

Research was conducted during 1989-1990 and 1990-1991, November to May, at an eastern Nebraska site (University of Nebraska Agricultural Research and Development Center near Mead, NE) and during 1989-1990, December to May, at a western Nebraska site (Panhandle Research and Extension Center near Scottsbluff, NE). Plots were constructed in which the native soil was removed to a depth of $0.46 \mathrm{~m}$ and replaced with soils having defined textures. At the eastern site, soil textures investigated were a silty clay loam, which was the native soil $(8.0 \%$ sand, $63.6 \%$ silt, $28.4 \%$ clay; bulk density $=1.18 \mathrm{~g} / \mathrm{cm}^{3}$ ), a sandy loam $(75.7 \%$ sand, $14.6 \%$ silt, $9.7 \%$ clay; bulk density $=$ $\left.1.44 \mathrm{~g} / \mathrm{cm}^{3}\right)$, and a loam $(34.4 \%$ sand, $44.0 \%$ silt, $21.7 \%$ clay; bulk density $\left.=1.29 \mathrm{~g} / \mathrm{cm}^{3}\right)$. At the western site, egg survival was investigated in a fine sandy loam soil $(57.0 \%$ sand, $29.4 \%$ silt, $13.6 \%$ clay). Each soil texture plot was 6.1 by $12.2 \mathrm{~m}$ and replicated 4 times in a randomized complete block design.

Western corn rootworm eggs were obtained from a commercial insectary (French Agricultural Research, Lamberton, MN). The eggs were oviposited by western corn rootworm adults collected during the previous summer from a northeastern Nebraska site. Eggs (200 per dish) were placed into plastic petri dishes $(15.0 \mathrm{~cm}$ diameter $)$ in moistened soil corresponding to the soil texture treatment in the field. Each petri dish had a 7-cmdiameter hole covered with a piece of 60-mesh stainless steel screening on the top and bottom. Petri dishes were placed into a wooden frame so that the dishes could be buried into the soil at depths of $7.5,15.0$, and $30.0 \mathrm{~cm}$. The frames with petri dishes were placed into $20.3-\mathrm{cm}$-diameter holes in the field plots and then covered with soil. Before placement into the soil, frames with dishes were wrapped with an electric heating cable (Easy Heat, New Carlisle, IN) to facilitate recovery of the dishes during periods when the soil was frozen. This technique was a modification of the procedure used by Krysan et al. (1984). Twelve petri dish frames were buried into each soil texture plot within two $37.2-\mathrm{m}^{2}$ areas. One area was randomly selected within each soil texture plot and covered to a depth of $15.2 \mathrm{~cm}$ with straw and with corn stalk residue at the eastern and western sites, respectively, whereas, in the other $37.2-\mathrm{m}^{2}$ area, the soil surface was left bare. The residue cover treatment was intended to produce an increased range of soil environmental conditions. The straw residue was held in place with by staked pieces of plastic netting (Forestry Suppliers, Jackson, MS). The residue cover treatment was intended to produce an increased range of soil environmental conditions. Eggs were placed into the field on 1 December 1989 and 15 December 1989 at the eastern and western Nebraska sites, respectively, and on 5 November 1990.

Western corn rootworm eggs were sampled from all plots monthly from December to May at the eastern Nebraska site and from January to May at the western Nebraska site. During periods when the soil was frozen, the heating cables were activated $12 \mathrm{~h}$ before sampling to thaw the soil; 1 wooden frame was excavated per plot. The petri dishes were removed from the frame and returned to the laboratory for processing. Within $72 \mathrm{~h}$ of field sampling, the eggs were separated from the soil. The egg recovery process was a modification of the method used by Shaw et al. (1976) for westem corn rootworm and by Pass and Van Meter (1966) for alfalfa weevil. The soil and eggs were mixed with 1 liter of water. This mixture was poured through a 30 - and a 60 -mesh screen. The residue on the 60 -mesh screen was rinsed into a beaker with $300 \mathrm{ml}$ of water, a vortex was created with a spatula, and the water and suspended contents were poured through a Büchner funnel onto filter paper. This process was facilitated by a slight suction created by a vacuum pump. The soil particles were not suspended by the vortex and remained in the beaker.

Following recovery, the eggs on moist filter paper were counted, placed in a Parafilm (American National Can, Greenwich CT) sealed petri dish, and stored at $21.1^{\circ} \mathrm{C}$. The filter paper was treated with a $1,000 \mathrm{ppm}$ solution of benomyl to retard fungal growth (Oloumi-Sadeghi and Levine 1989). 
Table 1. ANOVA of percentage of egg survival from 1989-1990 and 1990-1991 studies at the eastern Nebraska site

\begin{tabular}{|c|c|c|c|c|c|}
\hline \multirow{2}{*}{ Main effect } & \multirow{2}{*}{$\mathrm{df}$} & \multicolumn{2}{|c|}{$1989-1990$} & \multicolumn{2}{|c|}{$1990-1991$} \\
\hline & & MS & $F$ & MS & F \\
\hline Block & 3 & 6.75 & 0.93 & 7.58 & 1.58 \\
\hline Soil texture & 2 & 14.16 & 1.95 & 2.32 & 0.49 \\
\hline Error (a) & 6 & 7.25 & - & 4.79 & - \\
\hline Surface residue & 1 & 237.74 & $80.96^{* *}$ & 206.95 & $20.55^{* *}$ \\
\hline Surface $\times$ soil & 2 & 1.91 & 0.56 & 12.21 & 1.21 \\
\hline Error (b) & 9 & 3.40 & - & 10.07 & - \\
\hline Depth & 2 & 217.51 & $75.69 * *$ & 158.14 & $31.44 * *$ \\
\hline Soil $\times$ depth & 4 & 2.37 & 0.79 & 1.28 & 0.25 \\
\hline Surface $\times$ depth & 2 & 49.79 & $17.49 * *$ & 55.94 & $11.12 * *$ \\
\hline Soil $\times$ surface $\times$ depth & 4 & 3.34 & 1.18 & 7.34 & 1.46 \\
\hline Error (c) & 36 & 1.89 & - & 5.03 & - \\
\hline Time & 5 & 35.89 & $27.30^{* *}$ & 1.45 & 0.58 \\
\hline Time $\times$ soil & 10 & 1.81 & 1.38 & 1.87 & 0.74 \\
\hline Time $\times$ surface & 5 & 7.87 & $5.99 * *$ & 10.35 & $4.11^{* *}$ \\
\hline Time $\times$ depth & 10 & 9.59 & $7.30 * *$ & 6.60 & $2.61^{* *}$ \\
\hline Time $\times$ soil $\times$ surface & 10 & 1.80 & 1.37 & 1.55 & 0.62 \\
\hline Time $\times$ soil $\times$ depth & 20 & 0.01 & 0.01 & 0.02 & 0.01 \\
\hline Time $\times$ surface $\times$ depth & 10 & 2.21 & 1.68 & 4.33 & 1.72 \\
\hline Time $\times$ soil $\times$ surface $\times$ depth & 40 & 0.84 & 0.64 & 1.75 & 0.69 \\
\hline Error $(d)$ & 270 & 1.31 & - & 2.52 & - \\
\hline
\end{tabular}

$* *, P<0.05$.

Eclosion was monitored 3 times per week; all neonates were removed and counted. This process was continued until no eclosion was noted for 3 weeks consecutively. Egg survival was based on the number of eggs that eclosed out of the 200-egg sample placed in the field.

At the time of placement in the field, a subsample of eggs was placed on filter paper within petri dishes ( 28 petri dishes of 200 eggs each) and stored within a controlled environment at $4^{\circ} \mathrm{C}$. Four dishes were removed from these conditions concurrent with the timing of field sampling and placed at $21.1^{\circ} \mathrm{C}$. Eclosion of these eggs was monitored to determine egg viability over time.

Environmental conditions, soil and air temperature, were monitored in all treatments within one block at both sites. Soil temperature was monitored at $7.5,15.0$, and $30.0 \mathrm{~cm}$ and air temperature was measured $1 \mathrm{~m}$ above ground. Temperatures were recorded and stored with soil temperature probes and a data logger (probe Model 107B and data logger Model CR-21; Campbell, Logan UT). In addition, soil moisture was quantified on each sample date by removing a small soil sample at 7.5 , 15.0 , and $30.0 \mathrm{~cm}$. These samples were weighed wet and again following drying at $90^{\circ} \mathrm{C}$ for $48 \mathrm{~h}$. Precipitation, snowfall, and snow depth data were collected at weather stations located $\approx 8 \mathrm{~km}$ from the field sites.

Statistical Analyses. Analysis of variance (ANOVA) was used to examine the influence of the depth, soil texture, surface residue, and time main effects on egg survival (SAS Institute 1985). A split-split-split plot statistical design was used with soil texture as the main plots and depth, residue and time as the split plots. Least significant difference tests were used to separate means.
Forward stepwise regression analyses (SAS Institute 1985) were used to examine the relationship between egg survival and environmental conditions. Accumulated negative degree-days (from a $0^{\circ} \mathrm{C}$ base), minimum temperature, number of times from a frozen to thawed state, percentage soil moisture, days with $>2.5 \mathrm{~cm}$ snow cover, snowfall (centimeters), and precipitation (centimeters) were used as the independent variables. Linear, quadratic and cubic terms were considered.

\section{Results}

Percentage of Egg Survival (1989-1990): Eastern Nebraska Site. Western corn rootworm egg survival was significantly affected by the surface residue and depth main effects and by the interactions between these factors (Table 1). Egg survival averaged $37.4 \%$ in the residue-covered treatment compared with only $22.6 \%$ in the baresurface treatment (Fig. 1). Egg survival across the depths was $17.8,29.9$, and $42.3 \%$ at $7.5,15.0$, and $30.0 \mathrm{~cm}$, respectively. With the residue $\times$ depth interaction, egg survival was similar in the surfacecovered and bare plots at $30.0 \mathrm{~cm}$. However, at 15.0 and $7.5 \mathrm{~cm}$, the survival was $21.5 \%$ higher in the plots with surface residue compared with plots without surface residue. The time factor was also significant (Table 1). Overall, egg survival was highest in January, February, April, and May (averaging $33.5 \%)$, intermediate in March (29.9\%), and lowest in December (16.0\%). The low survival in December across all treatments may be attributable to sampling anomaly (cold shock) on the eggs from extremely cold temperatures during the sampling period $\left(-26^{\circ} \mathrm{C}\right.$ air temperature and $-40^{\circ} \mathrm{C}$ wind chill temperature). Because the egg survival was 


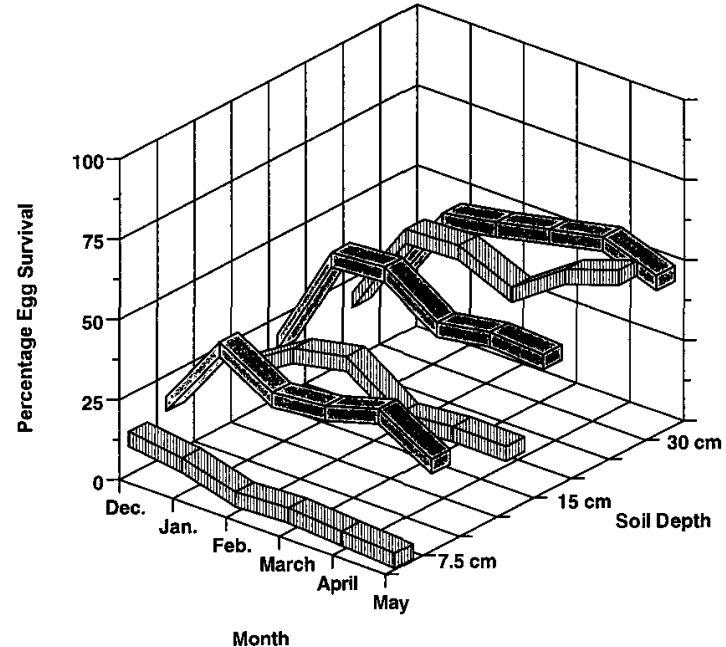

Fig. 1. Percentage of $D$. v. virgifera egg survival at several sampling intervals and 3 depths in soil in 19891990 at the eastern Nebraska site; , straw-surface residue cover; , bare surface.

higher on the subsequent sample dates (low survival in December does not reflect egg mortality in the soil); little biological significance can be placed on this result. Finally, significant interactions were found between time $X$ surface residue and time $X$ depth. The time $X$ surface residue interaction resulted primarily from similar egg survival between the residue-covered and bare surface plots in December; during the remaining months the survival was $\approx 20 \%$ higher in the residue than in the bare surface plots. For the time $x$ depth interaction, egg survival was low at all 3 depths in December and relatively constant at the 15.0 and $30.0 \mathrm{~cm}$ depths from January to May. A decrease in egg survival with time was noted at 7.5 $\mathrm{cm}$ (23.9\% in January to $14.5 \%$ in May).

Percentage of survival of $D$. v. virgifera eggs, held in the laboratory at $4^{\circ} \mathrm{C}$ until a time corresponding with each field sampling, averaged $64.3 \%$ $(49-78 \%)$. Survival did not change with time. Survival of laboratory-held eggs was consistently higher than that found in field samples except in January. On this sampling date, eclosion of the laboratory samples was $49 \%$ compared with an average of $52.8 \%$ for the straw-covered treatments.

Environmental Conditions (1989-1990): Eastern Nebraska Site. Air temperatures were coldest during December and February as a total of 134.5 and 105.6 negative degree-days (from a base of $0^{\circ} \mathrm{C}$ ) accumulated during December and February, respectively (Table 2). A minimum air temperature of $-31.7^{\circ} \mathrm{C}$ (with a wind chill of about $-65^{\circ} \mathrm{C}$ ) was reached in December. During this cold period, the data loggers malfunctioned. Therefore, temperatures were estimated from readings taken from a nearby weather station $(\approx 8$ $\mathrm{km}$ from study site). Measurements from bare soil (silty clay loam) were used as estimates for the bare
Table 2. Environmental conditions at the eastern Nebraska site in 1989-1990

\begin{tabular}{|c|c|c|c|c|c|c|}
\hline Month & $\begin{array}{c}\text { Min. } \\
\text { temp, }{ }^{\circ} \mathrm{C}\end{array}$ & $\begin{array}{c}\text { Avg } \\
\text { temp, }{ }^{\circ} \mathrm{C}\end{array}$ & $\begin{array}{c}\text { Negative } \\
\text { degree- } \\
\text { days, }{ }^{\circ} \mathrm{C}^{a}\end{array}$ & $\begin{array}{c}\text { Precipi- } \\
\text { tation } \\
\mathrm{cm}\end{array}$ & $\begin{array}{l}\text { Snow- } \\
\text { fall, } \\
\mathrm{cm}\end{array}$ & $\begin{array}{l}\text { Days } \\
\text { with } \\
\text { snow } \\
\text { cover }\end{array}$ \\
\hline $\operatorname{Dec}^{b}$ & -31.7 & -10.4 & 134.5 & 1.2 & 10.9 & 11 \\
\hline $\operatorname{Jan}^{c}$ & -25.0 & -1.3 & 29.7 & 0.5 & 4.3 & 8 \\
\hline Feb. & -16.4 & -1.6 & 105.6 & 1.9 & 17.8 & 11 \\
\hline Mar. & -6.1 & -4.4 & 1.6 & 5.8 & 0.0 & 4 \\
\hline April & 4.7 & 4.9 & 15.3 & 3.1 & 1.8 & 2 \\
\hline May & 1.1 & 13.7 & 0.0 & 7.2 & 0.0 & 0 \\
\hline
\end{tabular}

${ }^{a} 0^{\circ} \mathrm{C}$ base.

${ }^{b}$ From time of sample placement in field to sample date.

${ }^{c}$ From the time of sampling the previous month to the next month sampling.

soil treatments and those taken under bromegrass (Bromus sp.) were used as estimates for the surface-covered treatments in this study. Depths corresponding to $7.5,15$, and $30 \mathrm{~cm}$ were used. January was characterized by a minimum air temperature of $-25.0^{\circ} \mathrm{C}$; however, only 29.7 negative degree-days accumulated (Table 2). Freezing temperatures also occurred during March (average temperature $<0^{\circ} \mathrm{C}$ ) and during April

The highest levels of precipitation during the study occurred in March $(5.8 \mathrm{~cm})$ and May $(7.2$ $\mathrm{cm}$ ) (Table 2). The, greatest amounts of snowfall were in December $(10.9 \mathrm{~cm})$ and in February $(17.8 \mathrm{~cm})$ and the highest number of days with snow cover was during these months with $11 \mathrm{~d}$ each. In addition to these months, snow cover days were also recorded in January, March, and April.

Soil temperatures were generally lower and more variable in the bare surface compared with straw-covered treatments and at $7.5 \mathrm{~cm}$ compared with $30.0 \mathrm{~cm}$ (Table 3). There were no significant differences in temperature among the soil texture treatments. Soil temperatures, at all 3 depths, averaged $\angle 0^{\circ} \mathrm{C}$ during December and January. Negative degree-days accumulated in the straw-covered treatment in December to February (a total of 32.2 averaged over depths and textures) and in the bare-surface treatment in December to March (a total of 38.2 averaged over depths and textures). The minimum soil temperatures at $7.5 \mathrm{~cm}$ depth recorded from December to May were -5.0 and $-6.7^{\circ} \mathrm{C}$ in the $7.5-\mathrm{cm}$ depth surface-residue and bare soil treatments, respectively.

Soil moisture averaged $14.1 \%$ in the surface residue treatment compared with $13.6 \%$ bare soil surface treatment (Table 3 ). In addition, soil moisture was highest in the silty clay loam soil $(18.8 \%)$, intermediate in the loam soil $(14.0 \%)$, and lowest in the loamy sand soil (8.9\%). Soil moisture field capacity was also highest in the silty clay loam soil, intermediate in the loam soil, and lowest in the loamy sand soil. Soil moisture levels across the 3 depths in the soil showed no consistent trends.

Percentage of Egg Survival (1989-1990): Western Nebraska Site. Egg survival at the west- 
Table 3. Soil conditions, averaged over the 3 soil textures, at the eastern Nebraska site in $1989-1990$

\begin{tabular}{|c|c|c|c|c|c|c|c|c|c|c|c|c|}
\hline \multirow{2}{*}{ Month } & \multicolumn{3}{|c|}{ Min. temp, ${ }^{\circ} \mathrm{C}$} & \multicolumn{3}{|c|}{ Avg temp, ${ }^{\circ} \mathrm{C}$} & \multicolumn{3}{|c|}{$\begin{array}{c}\text { Negative } \\
\text { degree-days, }{ }^{\circ} \mathrm{C}^{a}\end{array}$} & \multicolumn{3}{|c|}{$\%$ moisture } \\
\hline & $7.5^{b}$ & 15 & 30 & 7.5 & 15 & 30 & 7.5 & 15 & 30 & 7.5 & 15 & 30 \\
\hline \multicolumn{13}{|c|}{ Straw-Covered } \\
\hline Dec ${ }^{c}$ & -5.0 & -4.4 & -3.9 & -1.0 & -0.9 & -0.2 & 21.1 & 19.2 & 13.3 & 13.3 & 13.3 & 13.3 \\
\hline $\operatorname{Jan}^{d}$ & -5.0 & -4.4 & -3.9 & -1.1 & -0.7 & -1.0 & 13.3 & 13.6 & 15.3 & 12.1 & 12.1 & 12.1 \\
\hline Feb. & 0.0 & -0.1 & -0.1 & 0.4 & 0.6 & 0.9 & 0.5 & 0.3 & 0.3 & 13.6 & 12.3 & 11.8 \\
\hline Mar. & 0.2 & 0.2 & 0.6 & 3.1 & 3.1 & 3.1 & 0 & 0 & 0 & 17.5 & 17.2 & 19.1 \\
\hline April & 3.6 & 3.2 & 2.4 & 5.3 & 6.0 & 5.4 & 0 & 0 & 0 & 12.4 & 13.3 & 10.4 \\
\hline May & 6.6 & 6.7 & 6.8 & 11.9 & 12.1 & 12.1 & 0 & 0 & 0 & 16.7 & 17.4 & 16.6 \\
\hline \multicolumn{13}{|c|}{ Bare Soil } \\
\hline Dec. & -6.7 & -3.9 & -3.9 & -2.1 & -0.7 & -0.7 & 27.7 & 16.1 & 15.0 & 11.7 & 11.7 & 11.7 \\
\hline Jan. & -5.6 & -4.4 & -4.4 & -1.3 & -1.1 & -1.2 & 20.2 & 13.3 & 15.3 & 11.9 & 11.9 & 11.9 \\
\hline Feb. & -0.9 & -0.7 & -2.1 & 1.8 & 0.5 & 0.9 & 3.1 & 1.6 & 2.0 & 12.5 & 11.9 & 11.4 \\
\hline Mar. & 0.2 & -0.1 & 0.2 & 4.3 & 4.5 & 4.7 & 0.1 & 0.1 & 0.2 & 19.2 & 18.1 & 18.4 \\
\hline April & 3.7 & 3.4 & 3.4 & 7.4 & 7.4 & 7.4 & 0 & 0 & 0 & 10.8 & 12.7 & 10.9 \\
\hline May & 6.1 & 7.0 & 6.9 & 13.3 & 13.9 & 14.2 & 0 & 0 & 0 & 14.5 & 16.0 & 17.1 \\
\hline
\end{tabular}

${ }^{a} 0^{\circ} \mathrm{C}$ base.

$b$ Soil depth, centimeters.

${ }^{c}$ From time of sample placement in field to sample date.

$d$ From the time of sampling the previous month to the next month sampling.

ern site was not significantly affected by surface residue or depth in soil (Table 4). Survival ranged from 39.6 to $42.7 \%$ across the 3 depths (Fig. 2). The only significant main effect was the time factor. Western corn rootworm egg survival was significantly higher in April and May (46.6\%) than in January to March (38.2\%). All interactions from the western site were not significant.

Environmental Conditions (1989-1990): Western Nebraska Site. Air temperatures, January to May, at the western site were generally warmer than at the eastern site. February was the only month during which the temperature averaged below $0^{\circ} \mathrm{C}$ (Table 5). The minimum temperature occurred during February at $-15.2^{\circ} \mathrm{C}$. In total, 56.9 negative degree-days accumulated from January to May compared with 152.2 during the same time period at the eastern Nebraska site.

Precipitation was considerably higher at the western site than at the eastern site; snowfall from January to May was $>4$-fold higher at the western Nebraska site than the easterm site (Tables 2 and

Table 4. ANOVA of percentage of egg survival from 1989-1990 study at the western Nebraska site in 1989_ 1990

\begin{tabular}{lrcc}
\hline \hline \multicolumn{1}{c}{ Main effect } & df & MS & $F$ \\
\hline Block & 3 & 0.55 & 0.28 \\
Surface residue & 1 & 1.01 & 0.51 \\
Error (a) & 3 & 1.99 & - \\
Depth & 2 & 1.11 & 1.55 \\
Surface $\times$ depth & 2 & 0.46 & 0.65 \\
Error (b) & 12 & 0.71 & - \\
Time & 4 & 5.42 & $9.77^{* *}$ \\
Time $\times$ surface & 4 & 0.65 & 1.18 \\
Time $\times$ depth & 8 & 0.31 & 0.56 \\
Time $\times$ surface $\times$ depth & 8 & 0.87 & 0.56 \\
Error (c) & 72 & 0.56 & - \\
\hline
\end{tabular}

4). High snowfall totals $(>28 \mathrm{~cm})$ occurred during each of February, March, and April at the western site. Total precipitation from January to May at the 2 sites was similar; however, the precipitation at the western site was more evenly distributed over the 5-mo period. Days with snow cover were also more prevalent at the western Nebraska site than at the eastern site during January to May.

Soil temperature averaged $\angle 0^{\circ} \mathrm{C}$ during only January and February in the residue-covered treatment $(7.5 \mathrm{~cm}$ only) and in the bare-soil treatment $(7.5,15.0$, and $30.0 \mathrm{~cm}$ ) (Table 6). Soil moisture, during periods with thawed soil, averaged $14.2 \%$ in the surface residue treatment and $13.1 \%$ in the bare surface treatment.

Percentage of Egg Survival (1990-1991). The surface residue main effect significantly affected egg survival (Table 1); however, overall egg survival was much higher in 1990-1991 than in 1989-1990 (Fig. 3). In the residue-covered treat-

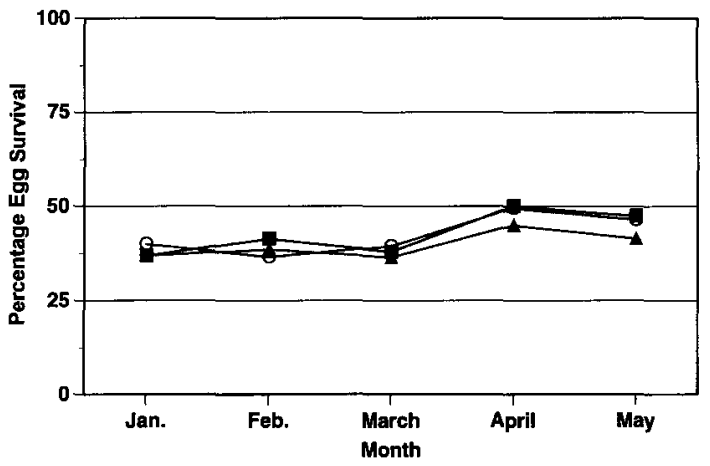

Fig. 2. Percentage of $D$. v. virgifera egg survival at several sampling intervals and 3 depths in soil in 19891990 at the western Nebraska site in sandy loam soil; $7.5 \mathrm{~cm}$ deep; $0,15 \mathrm{~cm}$ deep; $\boldsymbol{\Lambda}, 30 \mathrm{~cm}$ deep. 
Table 5. Environmental conditions at the western Nebraska site in 1989-1990

\begin{tabular}{crrrrrr}
\hline \hline Month & Min. temp, ${ }^{\circ} \mathrm{C}$ & Avg temp, ${ }^{\circ} \mathrm{C}$ & $\begin{array}{c}\text { Negative } \\
\text { degree-days, }{ }^{\circ} \mathrm{C}^{a}\end{array}$ & $\begin{array}{c}\text { Precipitation, } \\
\text { cm }\end{array}$ & $\begin{array}{c}\text { Snowfall, } \\
\text { cm }\end{array}$ & $\begin{array}{c}\text { Days with } \\
\text { snow cover }\end{array}$ \\
\hline Jan. ${ }^{b}$ & -1.9 & 4.5 & 1.5 & 0.7 & 9.7 & 9 \\
Feb. & -15.2 & -1.3 & 44.0 & 3.3 & 38.9 & 9 \\
Mar. & -5.7 & 2.0 & 4.8 & 5.3 & 28.2 & 35.1 \\
April & -9.1 & 5.0 & 8.7 & 4.9 & 3.8 & 0 \\
May & 0.0 & 10.3 & 0.0 & 4.2 & 4 \\
\hline
\end{tabular}

${ }^{a} 0^{\circ} \mathrm{C}$ base.

$b$ From time of sample placement in field to sample date.

$c$ From the time of sampling the previous month to the present month sampling.

ment, survival averaged $72.2 \%$ compared with only $58.3 \%$ in the bare-surface treatment. These values were $\approx 35 \%$ higher than in $1989-1990$. Across the 3 depths, egg survival was significantly higher at 15.0 and $30.0 \mathrm{~cm}$ (averaging $71.1 \%$ ) than at $7.5 \mathrm{~cm}$ $(53.3 \%)$. The surface residue $\times$ depth interaction was also significant. Egg survival was relatively constant across the 3 depths in the straw-covered plots (ranging from 67.6 to $76.2 \%$ ); however, survival increased substantially with increasing depth in the bare-surface plots. In this treatment, only $39.5 \%$ of the eggs survived at $7.5 \mathrm{~cm}$ compared with $71.3 \%$ at $30.0 \mathrm{~cm}$. The effect of time, as well as the block and soil texture main effects, were not significant. The time $\times$ surface cover and time $\times$ depth interactions were significant. Egg survival in both surface cover treatments averaged $66.8 \%$ in December. In the straw-covered treatment, survival increased in January and February to a peak of $\approx 71.8 \%$, whereas in the bare-surface treatment, over the same period, the survival decreased to $\approx 58.6 \%$ (Fig. 3). During December, percentage egg survival averaged 66,64 , and $71 \%$ at $7.5,15$, and $30 \mathrm{~cm}$, respectively. However, in May, the survival was only $48 \%$ at $7.5 \mathrm{~cm}$ compared with $77 \%$ at $30 \mathrm{~cm}$.

Survival of the eggs held in the laboratory at $4^{\circ} \mathrm{C}$ for varying periods and at $21.1^{\circ} \mathrm{C}$ ranged from 72.0 to $88.4 \%$. These values were slightly higher than survival of field-sampled eggs and also of eggs held in a similar manner in 1989-1990.

Environmental Conditions (1990-1991). Air temperatures averaged $<0^{\circ} \mathrm{C}$ during December, January, February, and March (Table 7). A minimum temperature of $-23.6^{\circ} \mathrm{C}$ was reached in January. In total, 467.0 negative degree-days, based on air temperatures, accumulated from December to May.

Precipitation, snow fall, and days with snow cover were higher in 1990-1991 than in 1989-1990 (Table 7). Substantial snowfall $(>15 \mathrm{~cm})$ occurred during December, January and February and more than half the days had snow cover during the latter 2 mo. During January and February, $40 \mathrm{~d}$ had snow cover compared with a total of $19 \mathrm{~d}$ during January and February, 1990.

Substantial negative degree-days accumulated (all 3 depths and 2 surface treatments) during January, February, March, and April (Table 8). Negative degree-day accumulation was generally greater in the bare than straw-covered surface treatment (for example, an average of 133.9 in the bare surface compared with 91.6 in the straw-covered treatment). Similarly, soil temperatures were generally lower as the soil depth decreased. Negative

Table 6. Soil conditions at the western Nebraska site in 1989-1990

\begin{tabular}{|c|c|c|c|c|c|c|c|c|c|c|c|c|}
\hline \multirow{2}{*}{ Month } & \multicolumn{3}{|c|}{ Min. temp, ${ }^{\circ} \mathrm{C}$} & \multicolumn{3}{|c|}{ Avg temp, ${ }^{\circ} \mathrm{C}$} & \multicolumn{3}{|c|}{$\begin{array}{c}\text { Negative } \\
\text { degree-days, }{ }^{\circ} \mathrm{C}^{a}\end{array}$} & \multicolumn{3}{|c|}{$\%$ moisture } \\
\hline & $7.5^{b}$ & 15 & 30 & 7.5 & 15 & 30 & 7.5 & 15 & 30 & 7.5 & 15 & 30 \\
\hline \multicolumn{13}{|c|}{ Residue-Covered } \\
\hline Jan. ${ }^{c}$ & -0.1 & 0.3 & 1.0 & 0.4 & 0.7 & 1.2 & 0.1 & 0.0 & 0.0 & - & - & - \\
\hline Feb. ${ }^{d}$ & -2.0 & 0.1 & 0.8 & -0.2 & 0.7 & 1.2 & 8.0 & 0.0 & 0.0 & - & - & - \\
\hline Mar. & -6.8 & 0.4 & 1.0 & -0.3 & 2.0 & 2.3 & 11.5 & 0.0 & 0.0 & - & - & - \\
\hline April & -5.9 & 2.7 & 3.0 & 3.6 & 5.1 & 5.0 & 3.9 & 0.0 & 0.0 & 15.1 & 14.6 & 13.9 \\
\hline May & 1.0 & 5.6 & 6.4 & 8.6 & 8.5 & 8.5 & 0.0 & 0.0 & 0.0 & 14.3 & 13.7 & 13.6 \\
\hline \multicolumn{13}{|c|}{ Bare Soil } \\
\hline Jan. & -0.9 & -1.1 & -0.3 & -0.3 & -0.5 & 0.0 & 2.5 & 3.1 & 0.5 & - & $\cdots$ & - \\
\hline Feb. & -2.8 & -1.9 & -0.3 & -0.5 & -0.3 & -0.2 & 9.2 & 5.3 & 0.5 & - & - & - \\
\hline Mar. & -0.6 & -0.1 & 0.3 & 2.0 & 2.0 & 2.1 & 0.0 & 0.0 & 0.0 & - & - & - \\
\hline April & 1.5 & 2.1 & 3.0 & 6.8 & 6.4 & 6.1 & 0.0 & 0.0 & 0.0 & 13.3 & 14.0 & 14.1 \\
\hline May & 3.8 & 5.4 & 7.1 & 11.5 & 11.0 & 10.5 & 0.0 & 0.0 & 0.0 & 11.1 & 12.8 & 13.1 \\
\hline
\end{tabular}

a $0^{\circ} \mathrm{C}$ base.

$b$ Soil depth, centimeters.

$c$ From time of sample placement in field to sample date.

$d$ From the time of sampling the previous month to the present month sampling. 


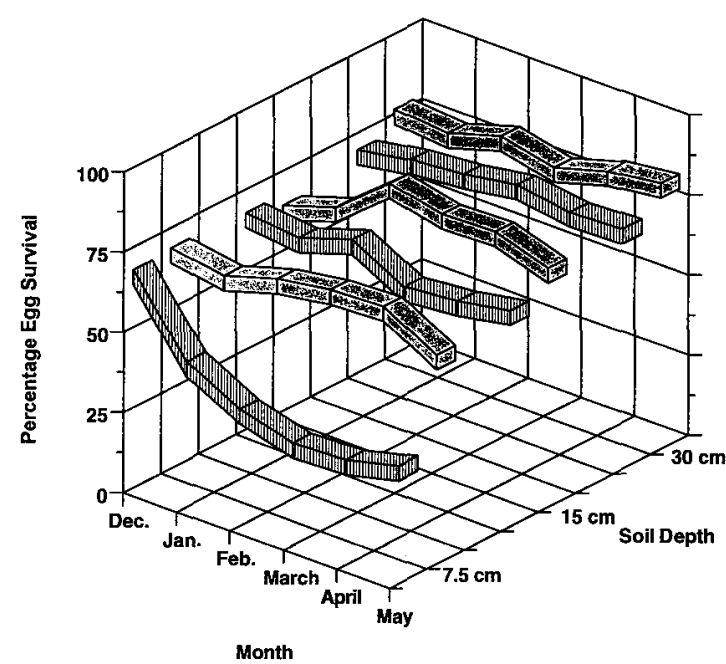

Fig. 3. Percentage $D$. v. virgifera egg survival at several sampling intervals and 3 depths in soil in 1990-1991 at the eastern Nebraska site; $\square$, straw-surface residue cover; bare surface.

degree-days averaged $162.9,129.0$, and 96.0 at 7.5, 15.0 , and $30.0 \mathrm{~cm}$, respectively.

Soil moisture did not differ significantly between the 2 surface residue treatments. However, there were substantial differences in soil moisture among the three soil texture treatments $(20.8 \%$ in the silty clay loam soil, $14.8 \%$ in the loam soil, and $10.4 \%$ in the loamy sand soil).

Egg Survival and Environmental Conditions. Simple regression equations of $D$. v. virgifera egg survival from the eastern site with accumulated negative degree-days (based on soil temperatures) and with minimum soil temperature were significant $(P<0.05)$; however, only $13.1-48.8 \%$ of the variation was explained (Table 9). Relationships with minimum soil temperature generally explained a greater amount of the variation than with negative degree-days. In 1989-1990, percentage of egg eclosion was relatively constant at $\approx 40 \%$ until minimum temperature of $-6^{\circ} \mathrm{C}$ was reached (no trends with negative degree-days were evident). Percentage of egg eclosion in 1990-1991 decreased significantly at $\approx 80$ negative degree-days and at a minimum temperature of $-7^{\circ} \mathrm{C}$. The relationship between egg eclosion and minimum soil temperature or negative degree-days was not significant at the western site.

Multiple regression models explained a greater percentage of the variation than simple models. Egg eclosion was influenced by negative degreedays (1st and 2nd order terms) and minimum soil temperature at the eastern site and by average soil temperature, negative degree-days, and days of snow cover and snow fall amount at the western site in 1989-1990 (Table 10). In 1990-1991, percentage soil moisture, minimum soil temperature, negative degree-days, and snow incidence (days of snow cover and snow fall amount) affected egg sur-
Table 7. Environmental conditions at the eastern Nebraska site in 1990-1991

\begin{tabular}{|c|c|c|c|c|c|c|}
\hline Month & $\begin{array}{c}\text { Min. } \\
\text { temp, }{ }^{\circ} \mathrm{C}\end{array}$ & $\begin{array}{c}\text { Avg } \\
\text { temp, }{ }^{\circ} \mathrm{C}\end{array}$ & $\begin{array}{c}\text { Negative } \\
\text { degree- } \\
\text { days, }{ }^{\circ} \mathrm{C}^{a}\end{array}$ & $\begin{array}{c}\text { Precipi- } \\
\text { tation, } \\
\mathrm{cm}\end{array}$ & $\begin{array}{c}\text { Snow- } \\
\text { fall, } \\
\mathrm{cm}\end{array}$ & $\begin{array}{l}\text { Days } \\
\text { with } \\
\text { snow } \\
\text { cover }\end{array}$ \\
\hline $\operatorname{Dec}^{b}$ & -7.4 & 3.4 & 26.2 & 2.2 & 18.3 & 7 \\
\hline $\operatorname{Jan}^{c}$ & -23.6 & -13.6 & 327.2 & 2.5 & 17.0 & 19 \\
\hline Feb. & -19.1 & -2.2 & 81.7 & 0.7 & 15.7 & 21 \\
\hline Mar. & -12.0 & -2.4 & 30.2 & 4.6 & 7.6 & 3 \\
\hline April & 1.6 & 3.5 & 0.0 & 10.2 & 2.5 & 1 \\
\hline May & -3.4 & 10.2 & 1.7 & 4.6 & 0.0 & 0 \\
\hline
\end{tabular}

${ }^{a} 0^{\circ} \mathrm{C}$ base.

${ }^{b}$ From time of sample placement in field to sample date.

${ }^{c}$ From the time of sampling the previous month to the present month sampling.

vival. These factors explained from 63.3 to $70.2 \%$ of the variation in egg survival.

\section{Discussion}

Egg survival in this study averaged 30.0 and $65.3 \%$ at the eastern study site in 1989-1990 and $1990-1991$, respectively, and $41.6 \%$ at the western study site in 1989-1990. This yearly variation mirrors that shown in previous studies. Calkins and Kirk (1969) found substantial variation in Diabrotica larval populations in South Dakota in 19651967 and assumed this was because of differential egg survival. They attempted to correlate these differences with minimum soil temperature, negative degree-days, and the number of days with temperatures $\angle 0^{\circ} \mathrm{C}$; however, years with the most severe winter environmental conditions did not have the lowest larval densities the next spring. Soil moisture (lack of precipitation during the winter) provided the best explanation of egg survival and resulting larval densities. Gustin (1981) and Gustin and Wilde (1985) examined D. v. virgifera egg survival with varying periods of freezing temperatures. Eggs exposed to $-7.5^{\circ} \mathrm{C}$ for $1 \mathrm{wk}$ eclosed equally as well as eggs held at $10^{\circ} \mathrm{C}$; however, $2-4$ wk exposure at $-7.5^{\circ} \mathrm{C}$ resulted in a decrease in survival (Gustin 1981). Exposure of eggs to $-10^{\circ} \mathrm{C}$ for $2-4$ wk resulted in substantial egg mortality. Egg eclosion for eggs at $-10^{\circ} \mathrm{C}$ for 4 wk was only $1.6 \%$ compared with $89.8 \%$ for eggs held at $10^{\circ} \mathrm{C}$ for 4 wk. Woodson and Gustin (1993) also observed reduced survival of $D$. v. virgifera eggs held for $4 \mathrm{wk}$ at $-7.5^{\circ} \mathrm{C}$ compared with eggs held at $0^{\circ} \mathrm{C}$. Low temperature was concluded to be an important factor in overwintering egg survival.

Lawson (1986) found that $D$. v. virgifera overwintering egg survival was not affected by soil tillage treatments or egg depth in soil in 1982-1983, but was significantly affected by these factors in 1983-1984. Percentage egg survival in 1983-1984 averaged $81.7 \%$. Percentage of eclosion of eggs overwintered during 1982-1983 increased with increasing depth in soil from $\approx 18 \%$ at $2.5 \mathrm{~cm}$ to $\approx 57 \%$ at $22.5 \mathrm{~cm}$. The considerably colder air tem- 
Table 8. Soil conditions, averaged over the 3 soil textures, at the eastern Nebraska site in 1990-1991

\begin{tabular}{|c|c|c|c|c|c|c|c|c|c|c|c|c|}
\hline \multirow{2}{*}{ Month } & \multicolumn{3}{|c|}{ Min. temp, ${ }^{\circ} \mathrm{C}$} & \multicolumn{3}{|c|}{ Avg temp; ${ }^{\circ} \mathrm{C}$} & \multicolumn{3}{|c|}{$\begin{array}{c}\text { Negative } \\
\text { degree-days, }{ }^{\circ} \mathrm{C}^{a}\end{array}$} & \multicolumn{3}{|c|}{$\%$ moisture } \\
\hline & $7.5^{b}$ & 15 & 30 & 7.5 & 15 & 30 & 7.5 & 15 & 30 & 7.5 & 15 & 30 \\
\hline \multicolumn{13}{|c|}{ Straw-Covered } \\
\hline Dec. $^{c}$ & 2.1 & 1.2 & 4.7 & 7.0 & 6.5 & 7.1 & 0.0 & 2.0 & 0.0 & 13.0 & 12.9 & 13.5 \\
\hline $\operatorname{Jan}^{d}$ & -0.4 & 0.1 & 1.1 & 0.9 & 1.0 & 2.1 & 12.1 & 9.9 & 2.1 & 16.7 & 17.0 & 15.9 \\
\hline Feb. & -2.5 & -2.0 & -1.0 & -0.6 & -0.3 & 0.1 & 39.0 & 30.8 & 17.7 & 14.5 & 13.6 & 13.6 \\
\hline Mar. & -3.7 & -2.7 & -1.9 & -0.8 & -0.7 & -0.4 & 38.3 & 28.9 & 28.9 & 17.3 & 16.1 & 15.5 \\
\hline April & -1.3 & -1.4 & -1.1 & 0.3 & 0.6 & 0.4 & 21.2 & 18.7 & 16.7 & 15.7 & 13.8 & 16.1 \\
\hline May & 7.3 & 7.5 & 4.6 & 11.4 & 11.0 & 11.0 & 0 & 0 & 0 & 16.7 & 17.4 & 16.6 \\
\hline \multicolumn{13}{|c|}{ Bare Soil } \\
\hline Dec. & 0.6 & 2.4 & 3.8 & 6.3 & 6.9 & 7.0 & 0.0 & 0.0 & 0.0 & 12.2 & 12.6 & 13.0 \\
\hline Jan. & -3.0 & -1.6 & -0.1 & -0.5 & 1.9 & 1.2 & 35.5 & 26.1 & 13.8 & 18.0 & 17.0 & 15.5 \\
\hline Feb. & -8.1 & -6.2 & -4.0 & -2.7 & -1.9 & -0.8 & 75.0 & 52.9 & 32.1 & 13.5 & 13.1 & 14.5 \\
\hline Mar. & -6.0 & -4.8 & -3.5 & -1.8 & -1.5 & -1.2 & 71.1 & 61.0 & 48.5 & 16.6 & 16.4 & 16.7 \\
\hline April & -3.0 & -2.3 & -1.7 & -0.4 & 0.0 & -0.2 & 28.0 & 24.5 & 27.9 & 15.7 & 15.1 & 16.7 \\
\hline May & 6.5 & 7.4 & 6.8 & 12.0 & 11.8 & 11.4 & 0 & 0 & 0 & 14.5 & 16.0 & 17.1 \\
\hline
\end{tabular}

${ }^{a} 0^{\circ} \mathrm{C}$ base.

$b$ Soil depth, centimeters.

${ }^{c}$ From time of sample placement in field to sample date.

${ }^{d}$ From the time of sampling the previous month to the present month sampling.

peratures during 1982-1983 compared with 198384 probably contributed to these differences. Moreover, based on the 1983-1984 data, Lawson (1986) calculated a $0.38 \%$ decrease in egg survival for every accumulated negative degree-day $\left(-1^{\circ} \mathrm{C}\right.$ threshold). Data from the previous year (milder winter) showed no significant egg mortality with 50 negative degree-days.

The most substantial overwintering $D$. v. virgifera egg mortality in our study occurred during 1989-1990 in the bare surface treatments at a 7.5$\mathrm{cm}$ depth. Survival in the sandy loam soil was $<5 \%$. Egg survival in the $7.5 \mathrm{~cm}$, straw-covered treatments was intermediate. In addition, at $15 \mathrm{~cm}$, survival was also affected significantly in the bare soil treatments. Environmental conditions (minimum and average temperatures and soil moisture) were more stressful in the bare soil treatments than in the straw-covered treatments, especially at $7.5 \mathrm{~cm}$. However, an average of only 51.1 negative degree-days accumulated in the $7.5 \mathrm{~cm}$, bare-surface treatments, which is in the range previously shown to have negligible effects on egg survival. Regression analyses showed a relatively poor relationship between egg survival and negative degree- days. Minimum temperature was $-6.7^{\circ} \mathrm{C}$ in the 7.5 cm depth, straw-covered treatment, which was less than the $-6^{\circ} \mathrm{C}$ egg survival threshold. Deficit soil moisture conditions may have contributed to the egg mortality. Precipitation was low during December 1989 through February $1990(3.7 \mathrm{~cm})$ and measurable snow cover was recorded on only $39 \%$ of the days during this span. Percentage of soil moisture in the sandy loam and loam soils averaged $10 \%$ from December to February and periods of very low soil moisture (5\%) occurred at the shallow soil depths during this time. In addition, the infrequent soil moisture evaluation used in this study may have missed transient periods of low soil moisture.

At the western study site in 1989-1990, egg mortality was substantial (an average of $41.6 \%$ eclosion); however, no significant differences occurred among the depth and surface cover treatments. Soil temperatures were moderate with a maximum of 23.5 accumulated negative degreedays; temperatures were slightly lower in the residue-covered than in the bare treatments. Snowfall, snow cover, and precipitation were much higher at the western site than at the eastern Nebraska

Table 9. Simple regression of $D$. v. virgifera overwintering egg survival with temperature conditions (negative degree-days and minimum temperature) in 1989-1990 at the eastern Nebraska and at the western Nebraska sites and in 1990-1991

\begin{tabular}{|c|c|c|c|c|c|}
\hline Year & Equation & $\mathrm{df}$ & $F$ & $P$ & $R^{2}$ \\
\hline \multicolumn{6}{|l|}{ Simple Regressions } \\
\hline \multirow[t]{2}{*}{$1989-1990$ (eastern site) } & $y=40.73-0.0094\left(\mathrm{NDD}^{2}\right)$ & 1,106 & 15.95 & 0.001 & 13.1 \\
\hline & $y=56.4-1.11\left(\right.$ mintemp $\left.{ }^{2}\right)$ & 1,106 & 74.00 & 0.001 & 41.1 \\
\hline 1989-1990 (western site) & $\begin{array}{l}\text { No significant relationships } \\
\text { with NDD or mintemp }\end{array}$ & & & & \\
\hline \multirow[t]{2}{*}{$1990-1991$} & $y=71.2-0.0023\left(\mathrm{NDD}^{2}\right)$ & 1,106 & 60.04 & 0.001 & 36.2 \\
\hline & $y=74.5-0.44\left(\right.$ mintemp $\left.^{2}\right)$ & 1,106 & 83.95 & 0.001 & 48.8 \\
\hline
\end{tabular}


Table 10. Multiple regression of $D$. v. virgifera overwintering egg survival with environmental conditions in 1989 1990 at the eastern Nebraska and at the western Nebraska sites and in 1990-1991

\begin{tabular}{|c|c|c|c|c|c|}
\hline Year & Equation $^{a}$ & $\mathrm{df}$ & $F$ & $P$ & $R^{2}$ \\
\hline 1989-1990 (eastern site) & $\begin{aligned} y= & 63.3+27.6(\text { mintemp })-0.159\left(\text { mintemp }^{3}\right) \\
& +4.41(\mathrm{NDD})-0.056\left(\mathrm{NDD}^{2}\right)\end{aligned}$ & 4,103 & 47.91 & 0.001 & 65.0 \\
\hline 1989-1990 (western site) & $\begin{aligned} y= & 33.3-2.35(\text { avgtemp })+0.00017\left(\text { NDD }^{3}\right) \\
& -0.058\left(\text { snowdays }^{2}\right)+1.19(\text { snowfall })-0.024\left(\text { snowfall }^{2}\right)\end{aligned}$ & 5,24 & 11.31 & 0.001 & 70.2 \\
\hline $1990-91$ & $\begin{aligned} y= & 84.8-0.36(\% \text { mois })+0.051 \text { (mintemp) }-0.00097\left(\mathrm{NDD}^{2}\right) \\
& +0.35 \text { (snowdays })-0.028\left(\text { snowfall }^{3}\right)\end{aligned}$ & 5,102 & 35.16 & 0.001 & 63.3 \\
\hline
\end{tabular}

Mintemp, minimum soil temperature $\left({ }^{\circ} \mathrm{C}\right)$; avgtemp, average soil temperature $\left({ }^{\circ} \mathrm{C}\right)$; NDD, negative degree-days $\left(0{ }^{\circ} \mathrm{C}\right.$ base $)$ from soil temperatures; snowdays, days with a minimum of $2.5 \mathrm{~cm}$ snow cover; snowfall, snowfall (cm), and \%mois, percentage soil moisture.

site in 1989-1990. This may have moderated the soil temperature and moisture effects.

In 1990-1991, significant egg mortality again occurred at the eastern study site. This trend was especially evident with the $7.5 \mathrm{~cm}$, bare soil treatments. Survival at $15 \mathrm{~cm}$ was substantially better in 1990-1991 than in 1989-1990. Environmental conditions during 1990-1991 were not as severe (minimum and average temperature) as in 19891990, especially during December and January. However, soil temperatures $<0^{\circ} \mathrm{C}$ persisted into April, which was different from 1989-1990. This may account for the gradual decline in egg survival throughout the sample periods. Temperatures were moderated by the soil surface residue and by the snow cover and this apparently affected the egg survival, especially at $7.5 \mathrm{~cm}$.

Depending on the surface residue and environmental conditions, $D$. v. virgifera egg survival can be significantly reduced up to a $15-\mathrm{cm}$ soil depth. Weiss et al. (1983) found that $80 \%$ of Diabrotica spp. eggs were in the upper $10 \mathrm{~cm}$ of soil in irrigated fields; in dryland production fields, $45 \%$ of the eggs were in this zone. Ball (1957) reported a $D$. virgifera virgifera egg distribution in the soil of 23,58 , and $81 \%$ in the upper 5,10 , and $15 \mathrm{~cm}$ of soil, respectively. Gray et. al (1992) found that $60 \%$ of $D$. virgifera virgifera egg population was located in the 20 - to $30-\mathrm{cm}$ soil depth zone. $D$. $v$. virgifera eggs are deposited deeper in the soil than $D$. longicornis eggs, apparently an evolutionary response to the lack of cold hardiness in D. v. virgifera (Krysan 1986).

Tillage may act as a negative or positive influence on egg survival. Patel and Apple (1967) found that plowing altered the distribution of $D$. longicornis (Say) eggs in the soil. Before tillage, 88 and $95.2 \%$ of the eggs were found in the upper 7.5 and $15 \mathrm{~cm}$ of soil, respectively. After plowing, egg distribution was $0 \%$ from 0 to $7.5 \mathrm{~cm}$ and $69.2 \%$ from 7.5 to $15 \mathrm{~cm}$. The remaining $31.8 \%$ were found below $15 \mathrm{~cm}$. In this manner, moldboard plowing may bury eggs deeper within the soil profile, therefore protecting eggs from the coldest soil temperatures. Conversely, tillage may bring eggs oviposited deeply in the soil up to shallower depths or it may also remove excessive crop residue. Surface residue, in this study, acted to insulate the soil and reduce egg mortality. A tillage practice that would remove the crop residue, without substantially disturbing the soil, may result in the greatest reduction in Diabrotica spp. egg overwintering survival; however, soil residue has other important functions (soil and moisture conservation) in the agroecosystem. The recent emphasis on no-till or minimum tillage corn production could result in increased $D$. v. virgifera egg survival and therefore higher larval populations.

The accuracy of using adult monitoring to predict the need for larval control the next spring should not be influenced directly by soil texture. Soil texture may influence egg survival as manifested by changes in soil moisture and soil temperature. Simple models using 1 or 2 factors have been successful in predicting overwinter egg survival, especially under laboratory conditions. However, factors such as soil moisture and temperature, which vary with soil depth and texture, and vary between and within years, make development of simple and highly predictable models of overwinter survival of $D$. v. virgifera eggs difficult.

\section{Acknowledgments}

We thank J. Brown and M. Barnhart (Department of Entomology, University of Nebraska) for their technical assistance. We thank K. Godfrey, K. Pruess, and J. Witkowski for their critical reviews of the manuscript. This research was supported by USDA-CSRS grant 89-341034326 and the University of Nebraska Agricultural Experiment Station projects 17-043 and 17-046. This is paper No. 10923 of the Journal Series of the University of Nebraska Agricultural Research Division and contribution No. 881 of the Department of Entomology, University of Nebraska-Lincoln.

\section{References Cited}

Ball, H. J. 1957. On the biology and egg-laying habits of the western corn rootworm. J. Econ. Entomol. 50: $126-127$.

Calkins, C. O., and V. M. Kirk. 1969. Effect of winter precipitation and temperature on overwintering eggs of northern and western corn rootworm. J. Econ. Entomol. 62: 541-543.

Elder, J. A. 1969. Soils of Nebraska. Conservation and Survey Division, University of Nebraska, Lincoln.

Foster, R. E., J. J. Tollefson, J. P. Nyrop, and G. L. Hein. 1986. Value of adult corn rootworm (Coleoptera: Chrysomelidae) population estimates in pest 
management decision making. J. Econ. Entomol. 79; $303-310$

Godfrey, L. D., and F. T. Turpin. 1983. Comparison of western corn rootworm (Coleoptera: Chrysomelidae) adult populations and economic thresholds in first-year and continuous corn fields. J. Econ. Entomol. 76: 1028-1032.

Gray, M. E., and J. J. Tollefson. 1988. Influence of tillage systems on egg populations of western corn and northern corn rootworms (Coleoptera: Chrysomelidae). J. Kans. Entomol. Soc. 61: 186-194.

Gray, M. E., G. L. Hein, M. A. Boethel, and D. D. Walgenbach. 1992. Western and northern corn rootworm (Coleoptera: Chrysomelidae) egg densities at three soil depths: implications for future ecological studies. J. Kans. Entomol. Soc. 65: 354-356.

Gustin, R. D. 1979. Effect of two moisture and population levels on oviposition of the western corn rootworm. Environ. Entomol. 8: 406-407.

1981. Soil temperature environment of overwintering western corn rootworm eggs. Environ. Entomol. 10: $483-487$.

Gustin, R. D., and G. E. Wilde. 1985. Cold hardiness of western corn rootworm (Coleoptera: Chrysomelidae) eggs from northern and southern zones of the corn belt. J. Kans. Entomol. Soc. 57: 722-725.

Johnson, T. B., and F. T. Turpin. 1985. Northern and western corn rootworm (Coleoptera: Chrysomelidae) oviposition in corn as influenced by foxtail populations and tillage systems. J. Econ. Entomol. 78: 57-60.

Krysan, J. L. 1986. Introduction: biology, distribution, and indentification of pest Diabrotica, pp. 1-23. In J. L. Krysan and T. A. Miller [eds.], Methods for the study of pest Diabrotica. Springer, New York.

Krysan, J. L., J. J. Jackson, and A. C. Lew. 1984. Field termination of egg diapause in Diabrotica with new evidence of extended diapause in $D$. barberi (Coleoptera: Chrysomelidae). Environ. Entomol. 13: 1237-1240.

Lawson, E. C. 1986. Influence of tillage and depth in the soil on soil temperature and survival of overwin- tering western corn rootworm eggs. M.S. thesis, Iowa State University, Ames.

Oloumi-Sadeghi, H., and E. Levine. 1989. Controlling fungi that colonize eggs of the western corn rootworm in the laboratory. Entomol. Exp. Appl. 50: 271279.

Pass, B. C., and C. L. Van Meter. 1966. A method for extracting eggs of the alfalfa weevil from stems of alfalfa. J. Econ. Entomol. 59: 1294.

Patel, K. K., and J. W. Apple. 1967. Ecological studies on the eggs of the northern corn rootworm. J. Econ. Entomol. 60: 496-500.

Pruess, K. K., J. F. Witkowski, and E. S. Raun. 1974. Population suppression of western corn rootworm by adult control with ULV malathion. J. Econ. Entomol. 67: 541-545.

Rasmussen, D. E., and H. C. Chiang. 1967. Effects of some agronomic practices on corn rootworm populations. Proceedings North Central Branch Entomol. Soc. Am. 22: 95.

SAS Institute. 1985. SAS user's guide: statistics. SAS Institute, Cary, NC.

Shaw, J. T., R. D. Ellis, and W. H. Luckmann. 1976. Apparatus and procedure for extracting corn rootworm eggs from soil. Ill. Nat. Hist. Surv. Biol. Notes 96.

Stamm, D. E., Z B Mayo, J. B. Campbell, J. F. Witkowski, L. W. Anderson, and R. Kozub. 1985. Western corn rootworm (Coleoptera: Chrysomelidae) beetle counts as a means of making larval control recommendations in Nebraska. J. Econ. Entomol. 78: 794-798.

Weiss, M. J., Z B Mayo, and J. B. Newton. 1983. Influence of irrigation practices on the spatial distribution of corn rootworm (Coleoptera: Chrysomelidae) eggs in the soil. Environ. Entomol. 12: 1293-1295.

Woodson, W. D., and R. D. Gustin. 1993. Low temperature effects on hatch of western corn rootworm eggs (Coleoptera: Chrysomelidae). J. Kans. Entomol. Soc. 66: 104-107.

Received for publication 7 July 1994; accepted 24 April 1995. 